\title{
Post-harvest Evaluation of Bananas (Musa sp.) Cultivated in the Brazilian Semi-arid Region When Submitted to Cold Storage
}

\author{
José Aluisio de Araújo Paula ${ }^{1}$, Elizangela Cabral Santos ${ }^{2}$, Eudes de Almeida Cardoso ${ }^{3}$, \\ Roberto Pequeno de Sousa ${ }^{3}$, Janilson Pinheiro de Assis ${ }^{3}$, Marta Juvenia Andrade Oliveira Meinerz ${ }^{4}$, \\ Paulo César Ferreira Linhares ${ }^{3} \&$ Alexandre Lopes Macedo ${ }^{5}$ \\ ${ }^{1}$ Consultant, Instructor and Doctor in Plant Science, Brazilian Service to Support at Micro and Small Enterprises \\ of Rio Grande do Norte (SEBRAE-RN), Mossoró, RN, Brazil \\ ${ }^{2}$ Associate Professor, Department of Agronomic and Forestry Sciences, Federal Rural Semi-Arid University, \\ Mossoró, RN, Brazil \\ ${ }^{3}$ Jitirana Research Group, Department of Agronomic and Forestry Sciences, Federal Rural Semi-Arid University, \\ Mossoró, RN, Brazil \\ ${ }^{4}$ Master in Plant Science from Federal Rural Semi-Arid University, Mossoró, RN, Brazil \\ ${ }^{5}$ Graduated in Chemical Engineering from Federal Rural Semi-Arid University, Mossoró, RN, Brazil \\ Correspondence: José Aluisio de Araújo Paula, Consultant and Instructor, Brazilian Service to Support at Micro \\ and Small Enterprises of Rio Grande do Norte (SEBRAE-RN), Mossoró, RN, 59600-230, Brazil. E-mail: \\ aluisiopaula@gmail.com
}

$\begin{array}{ll}\text { Received: December 22, } 2018 & \text { Accepted: January 31, } 2019 \quad \text { Online Published: March 15, } 2019 \\ \text { doi:10.5539/jas.v11n4p395 } & \text { URL: https://doi.org/10.5539/jas.v11n4p395 }\end{array}$

The research is financed by Coordenação de Aperfeiçoamento de Pessoal de Nivel Superior-CAPES.

\begin{abstract}
This study evaluates the post-harvest quality of fruits of different banana cultivars regarding type of propagation when stored in cold at three different times at constant temperature. The experiment was carried out at the Fazenda Terra Santa in the semi-arid region of northeastern Brazil. We applied a completely randomized experiment in a $6 \times 3$ factorial, evaluating the post-harvest development of 'Prata-anã' and 'Pacovan' cultivars, propagated in three different ways and analyzed at three distinct times of storage in the cold. The following fruit quality variables were analyzed: soluble solids, vitamin $\mathrm{C}$ content, titratable acidity, and potential of hydrogen $(\mathrm{pH})$. The analysis of variance revealed a significant effect at $1 \%$ probability in all sources of variation of analyzed variables of Soluble Solids and $\mathrm{pH}$, for the unfolding treatments $\times$ storage time of the analyzed variables Vitamin $C$ and titratable acidity, and for the source of variation treatment of the vitamin $C$ variable. The 'Prata-anã' cultivar propagated by rhizome with "ceva" was the most efficient technique of propagation, providing good soluble solids and titratable acidity contents, but with the lowest $\mathrm{pH}$ values.
\end{abstract}

Keywords: titratable acidity, banana, cold storage, cultivars

\section{Introduction}

Banana is one of the most consumed fruits in the world, being produced in several tropical countries (Sousa et al., 2003). It ranks as a primary source of energy after corn, rice, and wheat. The use of bananas in flour processing provides high concentrations of starch and gives it importance as a food source and to industrial purpose. In countries such as Brazil and Venezuela, where most of the wheat is imported, it can be mixed with other cereals and vegetables with high starch content as sources of nutrients with lower costs (Pacheco-Delahaye \& Testa, 2005).

The State of Rio Grande do Norte stands out as the largest banana exporter in Brazil. The expansion of this crop with technological advances has raised employment and income, as well as consolidating the regional development model based on the productive poles of high competitiveness (Guerra et al., 2009).

According to the FAO (2015), the worldwide marketing of fruit products has grown more than five folds in the last twenty years. M. I. F. Chitarra and A. B. Chitarra (2005), discussing the post-harvest handling of fruits, 
stated that the lack of adequate postharvest techniques, transportation, and storage of these products, which are highly perishable, causes significant losses. In emerging countries, the losses of some products comprise about $50 \%$.

Researches carried out in the state of Minas Gerais pointed out that, in Brazil, the magnitude of losses from the producer to the consumer is considerable, which indicates an urgent need for cheap and straightforward processes to conserve foods, ensuring their stability and durability (Pontes, 2009).

This research aims to assess the post-harvest quality of fruits of different banana cultivars as a function of the type of propagation, and three different times of storage under refrigeration.

\section{Material and Methods}

The experiments were carried out at Terra Santa farm, Quixeré, Ceará ( $50^{\circ} 05^{\prime} 07.57^{\prime \prime}$ S- $\left.37^{\circ} 51^{\prime} 51.59^{\prime \prime} \mathrm{W}\right)$, located in the semi-arid region of northeastern Brazil (Baixo Jaguaribe growing region). According to the Köppen classification, the climate of this region is BSwh', that is, hot and dry.

The experimental area comprised seedlings of the cultivars 'Pacovan' and 'Prata-anã' grown in double rows, spacing $2.0 \times 2.0 \times 4.0 \mathrm{~m}$. For the 'Pacovan' cultivar, the treatments consisted of seedlings weighting equal 1.8 $\mathrm{kg}$ or more, propagated by rhizomes with and without "ceva" (Note 1), and by meristem. For the 'Prata-anã' cultivar, the seedlings weighted $2.0 \mathrm{~kg}$ or more, propagated by rhizomes with and without "ceva", and by meristem.

The treatments of rhizome propagation with "ceva" was made by the removal sprouts in the areas of cultivation of Terra Santa farm, with a later period of rest in the shade, under field conditions, and on the soil surface, until one day before its final transplanting. The seedlings were prepared by scraping for the elimination of leaves and excess roots, and subsequent immersion of rhizomes in solution with $1 \%$ liquid carbofuran dissolved in water for 15 minutes. The procedure of scrapping and immersion was also used in treatments of rhizome propagation without "ceva".

For the treatments with meristem, the meristematic seedlings were acquired at the EMBRAPA Cassava and Fruticulture-CNPMF (Cruz das Almas/BA) and sent to the greenhouse of UFERSA, where they were replicated and definitively transplanted to the experimental area.

Before the planting and after soil preparation, the physical-chemical analysis of the soil $(0-30 \mathrm{~cm}$ and $30-60 \mathrm{~cm}$ depth) and chemical analyzes of the water of the farm were carried out in the UFERSA soil laboratory. The results of soil and water analysis guided application of agricultural inputs. The soil preparation comprised plowing and harrowing the experimental area.

The care of plants in the field followed the recommendations of Queiroga (2015) in commercial production areas of Terra Santa farm. Thus, some macronutrients $(\mathrm{N}, \mathrm{K}, \mathrm{Mg}$, and $\mathrm{S}$ ) and micronutrients ( $\mathrm{M}, \mathrm{Zn}$, and $\mathrm{B})$ were supplied following the recommendations of a locally developed nutrient absorption curve. Part of other inputs such as organic matter and phosphorus ( $\mathrm{Fe}, \mathrm{Cu}$, and $\mathrm{Mo}$ ) were supplied during the period of phytosanitary prevention and control, through foliar and spray applications. The remaining of total nutrients in deficit were provided to plants through natural decomposition of dry matter left on soil during pruning, thinning, and cultural remains of shoots, flowering, and harvesting.

The water supply was carried out following the established weekly/daily reference evapotranspiration depth for the crop obtained as recommended by the FAO (Allen et al., 1998) for each stage of crop development, and its replacement was carried out through an artificial sprinkler irrigation system.

Harvesting occurred each week systematically from 358 days after planting. We marked the bunches before harvest to separate the experimental units by treatment and send them to the laboratory for further analysis.

After the arrival of each harvest in the laboratory, the bananas were screened, separating them in trays, duly identified with the treatment for the days of storage (15 and 20 days). In the first harvest, we choose some trays of bananas for analysis of the zero time, while the remaining were taken to an air-conditioned environment to simulate the storage conditions. From the second collection it was verified whether there would also be some treatment (s) of the $15 \mathrm{and} /$ or 20 day storage time (s) to be analyzed. After the respective screenings, the selected treatments were analyzed, the data of the variables required in the study were collected.

The experiment comprised a completely randomized design in a $6 \times 3$ factorial scheme, with three blocks and two replications per block. Thus, the bananas cultivars were propagated in three ways (by rhizome with "ceva" and without "ceva", and by meristem), analyzed in three times of storage ( 0 days or $0 \mathrm{dd}, 15$ days or $15 \mathrm{dd}$, and 20 days or $20 \mathrm{dd}$ ) at a cold storage at temperatures of $17 \pm 3{ }^{\circ} \mathrm{C}$ and relative air humidity of $88 \pm 3 \%$. 
The treatments were assigned as follows: (T1) 'Pacovan' cultivar propagated by rhizome seedling with "ceva" assessed at times $0 \mathrm{dd}, 15 \mathrm{dd}$, and $20 \mathrm{dd}$; (T2) 'Prata-anã' cultivar propagated by rhizome seedling with "ceva" analyzed at times $0 \mathrm{dd}, 15 \mathrm{dd}$, and $20 \mathrm{dd}$; (T3) 'Pacovan' reproduced by rhizome without "ceva" analyzed at times $0 \mathrm{dd}, 15 \mathrm{dd}$, and $20 \mathrm{dd}$; (T4) 'Pacovan' cultivar propagated by rhizome without "ceva" analyzed at times 0 dd, $15 \mathrm{dd}$, and $20 \mathrm{dd}$; treatment 5 (T5) 'Pacovan' cultivar propagated by meristem seedling examined at times 0 $\mathrm{dd}, 15 \mathrm{dd}$, and $20 \mathrm{dd}$; and (T6) reproduced by meristem analyzed at times $0 \mathrm{dd}, 15 \mathrm{dd}$, and $20 \mathrm{dd}$. All treatments were stored under refrigeration.

The following variables were analyzed: Soluble Solids ( $\left.{ }^{\circ} \mathrm{BRIX}\right)$; vitamin $\mathrm{C}$ content (mg/100 g); titratable acidity ( $\mathrm{g}$ of Malic acid/100g of pulp) and $\mathrm{pH}$. We followed the procedures described below.

Soluble Solids: We used the aqueous extract obtained from the disintegration and homogenization of the fruits. A fraction of one or two drops of the extract was transferred to the prism of the refractometer (ATAGO brand), removing the large particles before reading, according to the analytical standards of the Association of Official Analytical Chemistry (2002).

Vitamin C Content: We transferred $5 \mathrm{~mL}$ of ascorbic acid solution $(50 \mu \mathrm{g} / \mathrm{mL})$ to a $125 \mathrm{~mL}$ Erlenmeyer flask, which was filled until $50 \mathrm{~mL}$ with distilled water. The samples were titrated with a refrigerated Tillman's solution until the turning point (light pink) persisted for 15 seconds. The reagent is reduced from blue to colorless, and in acidic liquid it becomes pinkish. All reaction occurred with agitation, filtration, and titration of a $5 \mathrm{~mL}$ aliquot of the filtrate as described in the standardization of the Tillmans solution, according to the Analytical Standards of Strohecker and Henning (1967).

Titratable Acidity: We diluted $5 \mathrm{~g}$ of ground sample in $100 \mathrm{~mL}$ of distilled water and titrated with a standard $0.1 \mathrm{~N} \mathrm{NaOH}$ solution using phenolphthalein as an indicator. The result was expressed in $\mathrm{g}$ of malic acid. $100 \mathrm{~g}^{-1} \mathrm{of}$ pulp according to the Analytical Standards of the Adolfo Lutz Institute (2008).

Potential of Hydrogen ( $p H$ ): A ground sample of $10 \mathrm{~g}$ was diluted in $100 \mathrm{~mL}$ of distilled water and homogenized. The $\mathrm{pH}$ was measured by potentiometry using a digital $\mathrm{pH}$ meter (Digimed brand, DM-20 model), duly calibrated with solutions of 4.0 and $7.0 \mathrm{pH}$, according to the Analytical Standards of the Adolfo Lutz Institute (2008).

The data were submitted to analysis of variance through the $\mathrm{F}$ test and to tests of averages at 1 and $5 \%$ of probability. The sources of variation (Treatments-T1 to T6, and storage time- $00 \mathrm{dd}, 15 \mathrm{dd}$, and $20 \mathrm{dd}$ ), and the unfolding of treatments within each storage time were analyzed through Tukey test (Gomes, 2009). The statistics were done in the software SISVAR $\AA$ (Ferreira, 2017).

For all treatments, we generated senescence curves of using the Microsoft Excel (Office 2010®). Later, we tested the significance and confirmed the coefficients of the regressions and coefficients of determination of each curve on SISVAR ${ }^{\circledR}$ (Ferreira, 2017).

\section{Results and Discussion}

The treatments, times of storage significantly affected the soluble solids (SS) and $\mathrm{pH}$ of the bananas at $1 \%$ probability (Table 1). Treatments influenced the vitamin $\mathrm{C}$ content (Vit $\mathrm{C}$ ) also at $1 \%$ of probability. The treatments and times affected titratable acidity (TA) at $5 \%$ probability. The interaction between treatments and storage times influenced all variables at $1 \%$ of probability (Table 1 ).

Table 1. Analysis of variance for the post-harvest quality of bananas of Terra Santa Farm. Quixeré/CE, 2018

\begin{tabular}{|c|c|c|c|c|}
\hline Source of variation & SS $\left({ }^{\circ} \mathrm{BRIX}\right)$ & Vit. C (mg/100 g) & TA (g malic acid/100 g pulp) & $\mathrm{pH}$ \\
\hline Treatment & $0.00000 * *$ & $0.00000 * *$ & $0.01680 *$ & $0.00340 * *$ \\
\hline Time & $0.00000 * *$ & $0.64590^{\mathrm{ns}}$ & $0.01790 *$ & $0.00000 * *$ \\
\hline Treatment $\times$ Time & $0.00180 * *$ & $0.00020 * *$ & $0.00210 * *$ & $0.00050 * *$ \\
\hline $\mathrm{CV}(\%)$ & 48.55 & 23.22 & 35.30 & 2.85 \\
\hline General average & 2.48 & 459.66 & 2.26 & 5.40 \\
\hline Number of observations & 144 & 144 & 144 & 144 \\
\hline
\end{tabular}

Note. ${ }^{\text {ns }}$ not significant; * significant at 5\%; **significant at $1 \%$; SS: soluble solids content; Vit. C: vitamin C content; TA: titratable acidity; $\mathrm{pH}$ : hydrogen potential. 
All results of our experiment corroborate the findings of M. I. F. Chitarra and A. B. Chitarra (2005) for banana fruits harvested early at 90 days after the anthesis. Also, the storage under refrigeration was efficient in delaying the respiratory process of the fruits (Wills et al., 1981).

The use of the techniques tested in our study would enable the export of bananas, with as transportation requirement the storage under refrigeration of up to $17^{\circ} \mathrm{C}$, and destination to countries with a maximum distance of 20 days.

When the Tukey test was applied, it was observed that, among the treatments studied, the treatment 4 , formed by 'Prata-anã' banana seedlings propagated with "ceva" (T4), was the one that presented statistically the highest values of the test for soluble solids (at 1\% probability) and titratable acidity (at 5\% probability), being considered the most efficient form of propagation in obtaining results for these variables, since it exceeded the values obtained by meristem and rhizome propagation, both of the banana tree 'Pacovan' and 'Prata-anã' bananas, and the values obtained in the propagation with "ceva" of the 'Pacovan' banana (Tables 2 and 4).

According to Carvalho (1984), our results of soluble solids are within that expected for green bananas, which can vary from 1.5 to $5.2^{\circ} \mathrm{BRIX}$. Also, the T4 treatment exceeded the values of $0.14 \%$ of malic acid and $3.16^{\circ} \mathrm{BRIX}$ reported by Souza et al. (2013) for 'Prata-anã' bananas, in a survey carried out in Botucatú/SP (Tables 2 and 4).

Table 2. Mean values of soluble solids in banana fruits, referring to the unfolding of interaction between treatments and storage times. Quixeré/CE, $2018^{1}$

\begin{tabular}{llll}
\hline & T 00 dd & T 15 dd & T 20 dd \\
\hline T1 & $1.23^{\mathrm{AB}}$ & $1.85^{\mathrm{C}}$ & $4.01^{\mathrm{AB}}$ \\
$\mathrm{T} 2$ & $0.85^{\mathrm{AB}}$ & $2.73^{\mathrm{B}}$ & $3.04^{\mathrm{B}}$ \\
T3 & $1.50^{\mathrm{AB}}$ & $2.09^{\mathrm{C}}$ & $1.69^{\mathrm{C}}$ \\
T4 & $2.00^{\mathrm{A}}$ & $4.61^{\mathrm{A}}$ & $4.23^{\mathrm{A}}$ \\
T5 & $0.69^{\mathrm{B}}$ & $2.83^{\mathrm{B}}$ & $4.53^{\mathrm{A}}$ \\
T6 & $0.70^{\mathrm{B}}$ & $2.48^{\mathrm{C}}$ & $3.49^{\mathrm{AB}}$ \\
\hline
\end{tabular}

Note. ${ }^{1}$ In each row and column, the averages followed by the same letters, do not differ self according to the Tukey test Applied. T1: 'Pacovan' propagated with "ceva"; T2: 'Prata-anã' propagated with "ceva"; T3: 'Pacovan' propagated without "ceva"; T4: 'Prata-anã' propagated without "ceva”; T5: 'Pacovan' propagated by meristem; T6: 'Prata-anã' propagated by meristem; T 00 dd: 0 days of storage; T 15 dd: 15 days of storage; T 20 dd: 20 days of storage.

Still in relation to the soluble solids, all unfoldings of treatments (T1, T2, T4, T5, and T6) over the storage time $(0 \mathrm{dd}, 15 \mathrm{dd}$, and $20 \mathrm{dd})$, with the exception of T3 unfolding, showed a linear increase of values, with coefficient of determination $\left(\mathrm{R}^{2}\right)$ higher than $86 \%$ and significance equal to or higher than $5 \%$ probability. The $\mathrm{T} 3$ treatment was the least efficient in the evaluation of soluble solids (Table 2 and Figure 1). 


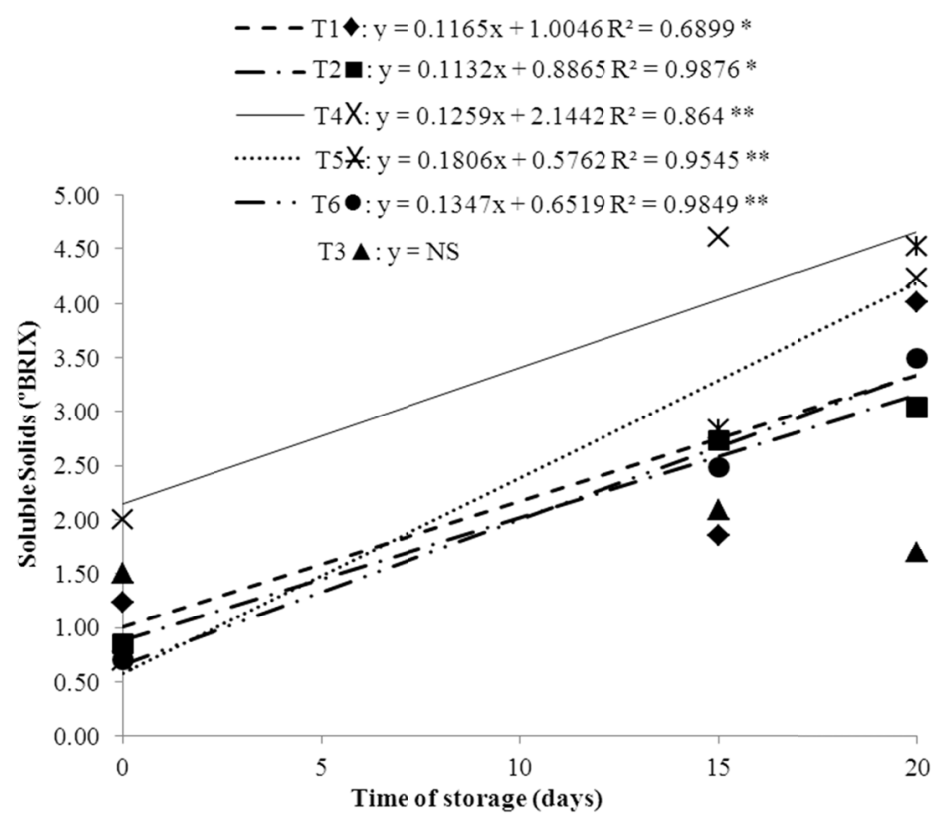

Figure 1. Post-harvest variation of soluble solids ( $\left.{ }^{\circ} \mathrm{BRIX}\right)$ over the storage time of bananas submitted to six treatments (T1 to T6) in Quixeré/CE, 2018

The highest rate of increase in soluble solids content (18.06\%) occurred in the T5 treatment ('Pacovan' propagation by meristem), which obtained a coefficient of determination of $95.45 \%$ and confidence level of $1 \%$ of probability. This treatment was the least efficient because allowed the highest respiratory rate of the banana. It was followed by T6 and T4 (propagation of 'Prata-anã' by meristem and by rhizome with "ceva", respectively), with the rates of increase of $13.47 \%$ and $12.59 \%$, respectively, both with a confidence level of $5 \%$ of probability (Wills et al., 1981) (Table 2 and Figure 1).

Finally, treatments T2 and T1 ('Prata-anã' and 'Pacovan' propagated by rhizome without "ceva", respectively) had the lowest rates of increase in soluble solids values. Therefore, these were the most effective treatments in the control of variations in soluble solids content along the time of storage. These treatments showed a coefficient of determination of $98.32 \%$ and $68.99 \%$, and an increasing rate of $11.32 \%$ and $11.65 \%$, respectively, with a confidence level of $1 \%$ probability (Table 2 and Figure 1 ).

The vitamin $\mathrm{C}$ values had a general average of $77.88 \mathrm{mg} / 100 \mathrm{~g}$. The treatments $\mathrm{T} 1$ at time $0 \mathrm{dd}$ and $\mathrm{T} 3$ at time 20 $\mathrm{dd}$ resulted, respectively, in the minimum and maximum values. These values represented, respectively, $101.4 \%$, $74.51 \%$, and $207.00 \%$ of the maximum values obtained by Amorim et al. (2011) in 61 unregistered banana cultivars, which was $76.82 \mathrm{mg} / 100 \mathrm{~g}$ (tetraploid 'Teparod'), and about $48.68 \%, 35.77 \%$, and $99.37 \%$ of the minimum values obtained by Menezes and Alves (1995) on the peduncle of the cashew (Tables 1 and 3).

Table 3. Mean values of vitamin $\mathrm{C}$ in banana fruits, referring to the unfolding of interaction between treatments and storage times. Quixeré/CE, $2018^{1}$

\begin{tabular}{llll}
\hline & T $00 \mathrm{dd}$ & T $15 \mathrm{dd}$ & T 20 dd \\
\hline T1 & $99.63^{\mathrm{C}}$ & $103.87^{\mathrm{C}}$ & $93.27^{\mathrm{C}}$ \\
$\mathrm{T} 2$ & $101.33^{\mathrm{C}}$ & $80.48^{\mathrm{B}}$ & $78.43^{\mathrm{B}}$ \\
$\mathrm{T} 3$ & $86.91^{\mathrm{BC}}$ & $103.87^{\mathrm{C}}$ & $69.95^{\mathrm{AB}}$ \\
T4 & $62.97^{\mathrm{A}}$ & $63.17^{\mathrm{AB}}$ & $78.22^{\mathrm{B}}$ \\
T5 & $52.66^{\mathrm{A}}$ & $62.54^{\mathrm{A}}$ & $82.39^{\mathrm{BC}}$ \\
T6 & $57.24^{\mathrm{A}}$ & $65.29^{\mathrm{AB}}$ & $59.57^{\mathrm{A}}$ \\
\hline
\end{tabular}

Note. ${ }^{1}$ In each row and column, the averages followed by the same letters, do not differ self according to the Tukey test Applied. T1: 'Pacovan' propagated with "ceva"; T2: 'Prata-anã' propagated with "ceva"; T3: 'Pacovan' propagated without "ceva"; T4: 'Prata-anã' propagated without "ceva"; T5: 'Pacovan' propagated by meristem; T6: 'Prata-anã' propagated by meristem; T $00 \mathrm{dd}$ : 0 days of storage; T $15 \mathrm{dd}: 15$ days of storage; T 20 dd: 20 days of storage. 
The vitamin $\mathrm{C}$ contents of 'Prata-anã' and 'Pacovan' cultivars had a lower capacity to meet an adult daily requirement intake ( 75 to $90 \mathrm{mg} /$ day, DRI, 2000 Apud Sant Anna, \& Russo, 2013) than the cashew peduncle (Menezes \&Alves, 1995). However, 50\% of our treatments (T1 and T3 in time 15 dd and T5 in time $20 \mathrm{dd}$ ) exceeded in $7.2 \%$ the maximum value obtained for the bananas of the 61 cultivars studied in Cruz das Almas (Amorim et al., 2011) (Table 3).

The results of unfolding the treatments T2, T3 and T5 over time showed a significant variation in vitamin C content, with mean values of $98.92,68.12$, and $60.70 \mathrm{~g}$ of malic acid/100 g of pulp, respectively (Table 3 and Figure 2). The unfolding of T1, T4, and T6 treatments over time showed a non-significant variation.

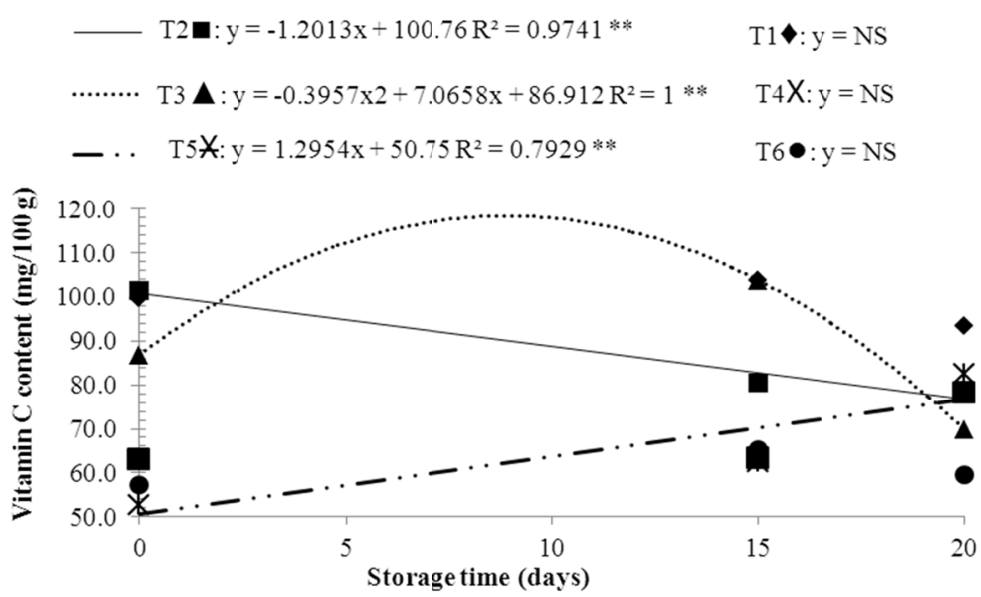

Figure 2. Post-harvest variation of vitamin $\mathrm{C}$ content $(\mathrm{mg} / 100 \mathrm{~g})$ over the storage time of bananas submitted to six treatments (T1 to T6) in Quixeré/CE, 2018

Regarding the unfolding of vitamin C, treatments $\mathrm{T} 2$ and $\mathrm{T} 5$ had linear increase rates over time of $1.20 \%$ and $1.29 \%$, respectively. Both presented a significance of $1 \%$ and a coefficient of determination higher than $79 \%$ (Table 3 and Figure 2).

Concerning $\mathrm{T} 3$ treatment, the vitamin $\mathrm{C}$ content varied in a quadratic way over time, showing the maximum determination coefficient $(\mathrm{R} 2=100 \%)$ and significance of $1 \%$ of probability. Vitamin C content increased until nine days $(120 \mathrm{mg} / 100 \mathrm{~g})$, after which, it decreased at the same rates until day 20 , when it obtained 69.95 $\mathrm{mg} / 100 \mathrm{~g}$ (Table 3 and Figure 2).

The titratable acidity of $\mathrm{T} 1, \mathrm{~T} 2, \mathrm{~T} 4$, and $\mathrm{T} 5$ treatments varied significantly over time, with $1 \%$ probability level. The treatments T3 and T6 ('Pacovan' with "ceva" and 'Prata-anã' propagated by meristem, respectively) did not vary significantly over time, obtaining average values of 2.40 and $1.96 \mathrm{~g}$ of malic acid/100 $\mathrm{g}$ of pulp, respectively. Thus, these treatments (T3 and T6) were the most effective in controlling fruit acidity, since their values remained statistically unchanged throughout the storage period (Table 4 and Figure 3 ).

Table 4. Mean values of titratable acidity in banana fruits, referring to the unfolding of interaction between treatments and storage times. Quixeré/CE, $2018^{1}$

\begin{tabular}{llll}
\hline & T $00 \mathrm{dd}$ & T $15 \mathrm{dd}$ & T 20 dd \\
\hline T1 & $1.75^{\mathrm{AB}}$ & $2.18^{\mathrm{BC}}$ & $2.93^{\mathrm{C}}$ \\
$\mathrm{T} 2$ & $1.61^{\mathrm{A}}$ & $2.97^{\mathrm{C}}$ & $2.49^{\mathrm{C}}$ \\
T3 & $2.70^{\mathrm{C}}$ & $2.17^{\mathrm{BC}}$ & $2.33^{\mathrm{BC}}$ \\
T4 & $2.12^{\mathrm{BC}}$ & $3.05^{\mathrm{C}}$ & $2.77^{\mathrm{C}}$ \\
T5 & $1.45^{\mathrm{A}}$ & $1.99^{\mathrm{B}}$ & $2.32^{\mathrm{BC}}$ \\
T6 & $2.40^{\mathrm{BC}}$ & $1.53^{\mathrm{A}}$ & $1.96^{\mathrm{B}}$
\end{tabular}

Note. ${ }^{1}$ In each row and column, the averages followed by the same letters, do not differ self according to the Tukey test Applied. T1: 'Pacovan' propagated with "ceva"; T2: 'Prata-anã' propagated with "ceva"; T3: 'Pacovan' propagated without “ceva”; T4: 'Prata-anã' propagated without “ceva”; T5: 'Pacovan' propagated by meristem; T6: 'Prata-anã' propagated by meristem; T $00 \mathrm{dd}: 0$ days of storage; T $15 \mathrm{dd}: 15$ days of storage; T 20 dd: 20 days of storage. 
The titratable acidity of treatments T1, T2, T4, and T5 showed increase rates of 5.20\%, 5.48\%, 3.93\%, and $4.18 \%$ over time, respectively, with significance of $1 \%$ for the first two and $5 \%$ for the last two, and determination coefficients of 82.14\%, 68.31\%, 73.53\%, and 97.98\%. The treatments T4 and T5 ('Prata-anã' with "ceva" and 'Pacovan' propagated by meristem) had intermediate values of titratable acidity control, whereas treatments T1 and T2 ('Pacovan' and 'Prata-anã' propagated by rhizome without "ceva”) were the least efficient in the control of this variable (Figure 3).

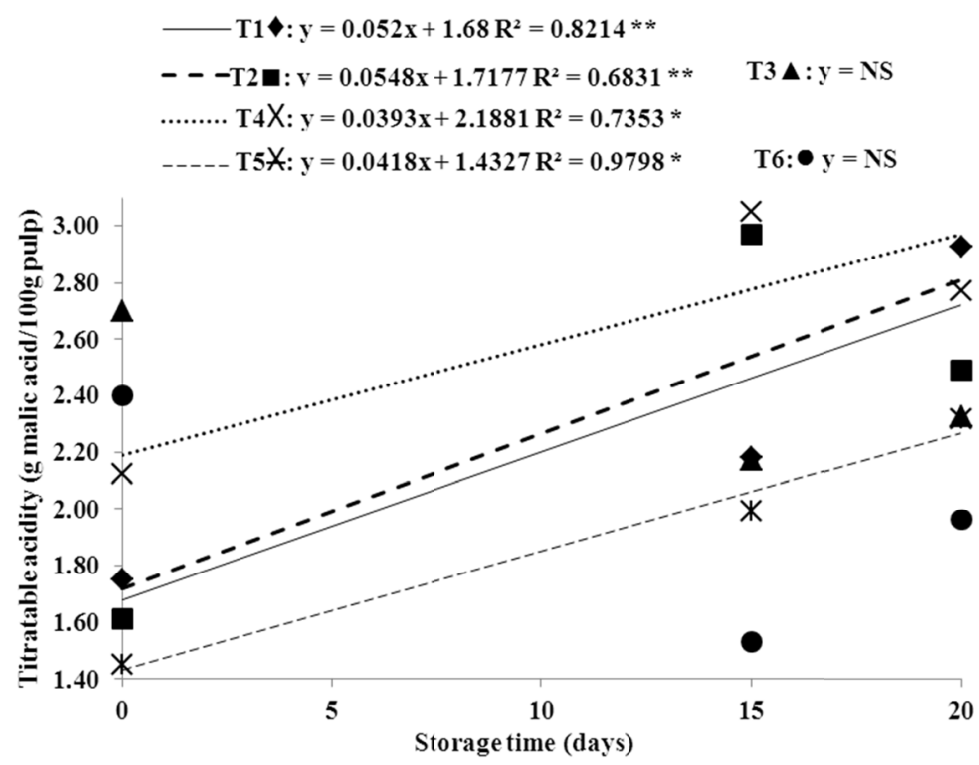

Figure 3. Post-harvest variation of titratable acidity ( $\mathrm{g}$ of malic acid/100 $\mathrm{g}$ of pulp) over the storage time of bananas submitted to six treatments (T1 to T6) in Quixeré/CE, 2018

The values of the different treatments (T1, T2, T3, T4, T5, T6 and T6) were representative for the storage period ( T $00 \mathrm{dd}, \mathrm{T} 15 \mathrm{dd}$ and T $20 \mathrm{dd}$ ) of its values symmetrically inverted during the studied storage time, and thus the T5 ( $\mathrm{pH} 5.43$ ), which obtained in T 00 dd the highest acidity content among the studied ones, the others being statistically similar to each other $(\mathrm{T} 1=\mathrm{pH} 5.58, \mathrm{~T} 2=\mathrm{pH} 5.61, \mathrm{~T} 3=\mathrm{pH} 5.57, \mathrm{~T} 4=\mathrm{pH} 5.60$ and $\mathrm{T} 6=\mathrm{pH} 5.62)$, in $\mathrm{T} 15 \mathrm{dd}$, $\mathrm{T} 5(\mathrm{pH} 5.46)$ were similar to the treatments $\mathrm{T} 6(\mathrm{pH} \mathrm{5.36)}$ and $\mathrm{T} 1 \mathrm{(pH} \mathrm{5.42)}$ and obtained the less acid values of the period, the others being similar to each other and the most acidic $(\mathrm{T} 2=\mathrm{pH} 5.23, \mathrm{~T} 3=\mathrm{pH} 5.29$ and $\mathrm{T} 4=\mathrm{pH} 5.16)$. For $\mathrm{T} 20 \mathrm{dd}, \mathrm{T} 5(\mathrm{pH} 5.35)$ did not differ from any of the treatments studied $(\mathrm{T} 1=\mathrm{pH} 5.25$, $\mathrm{T} 2=\mathrm{pH} 5.31, \mathrm{~T} 3=\mathrm{pH} 5.36, \mathrm{~T} 4=\mathrm{pH} 5.11$ and $\mathrm{T} 6=\mathrm{pH} 5.44), \mathrm{T} 1$ and $\mathrm{T} 4$ the most acidic and T6 the least acid for the period (Table 5).

Table 5. Mean values of $\mathrm{pH}$ in banana fruits, referring to the unfolding of interaction between treatments and storage times. Quixeré/CE. $2018^{1}$

\begin{tabular}{llll}
\hline & T $00 \mathrm{dd}$ & T $15 \mathrm{dd}$ & T 20 dd \\
\hline T1 & $5.58^{\mathrm{C}}$ & $5.42^{\mathrm{B}}$ & $5.25^{\mathrm{A}}$ \\
$\mathrm{T} 2$ & $5.61^{\mathrm{C}}$ & $5.23^{\mathrm{A}}$ & $5.31^{\mathrm{AB}}$ \\
$\mathrm{T} 3$ & $5.57^{\mathrm{C}}$ & $5.29^{\mathrm{A}}$ & $5.36^{\mathrm{AB}}$ \\
$\mathrm{T} 4$ & $5.60^{\mathrm{C}}$ & $5.16^{\mathrm{A}}$ & $5.11^{\mathrm{A}}$ \\
$\mathrm{T} 5$ & $5.43^{\mathrm{B}}$ & $5.46^{\mathrm{B}}$ & $5.35^{\mathrm{AB}}$ \\
T6 & $5.62^{\mathrm{C}}$ & $5.36^{\mathrm{AB}}$ & $5.44^{\mathrm{B}}$ \\
\hline
\end{tabular}

Note. ${ }^{1}$ In each row and column, the averages followed by the same letters, do not differ self according to the Tukey test Applied. T1: 'Pacovan' propagated with "ceva"; T2: 'Prata-anã' propagated with "ceva"; T3: 'Pacovan' propagated without "ceva"; T4: 'Prata-anã' propagated without “ceva”; T5: 'Pacovan' propagated by meristem; T6: 'Prata-anã' propagated by meristem; T 00 dd: 0 days of storage; T 15 dd: 15 days of storage; T 20 dd: 20 days of storage. 
The $\mathrm{pH}$ values of this experiment (Table 5 and Figure 4) in all treatments were equal to or higher than those found in the literature for 'Pacovan' (Leite et al., 2010) and 'Prata-anã' (Damatto Junior et al., 2005) developed in the same experimental conditions, which obtained values of 4.90 and 4.85 , respectively. Therefore, for the $\mathrm{pH}$ variable, the way of growing the plants and storing the fruits were efficient.

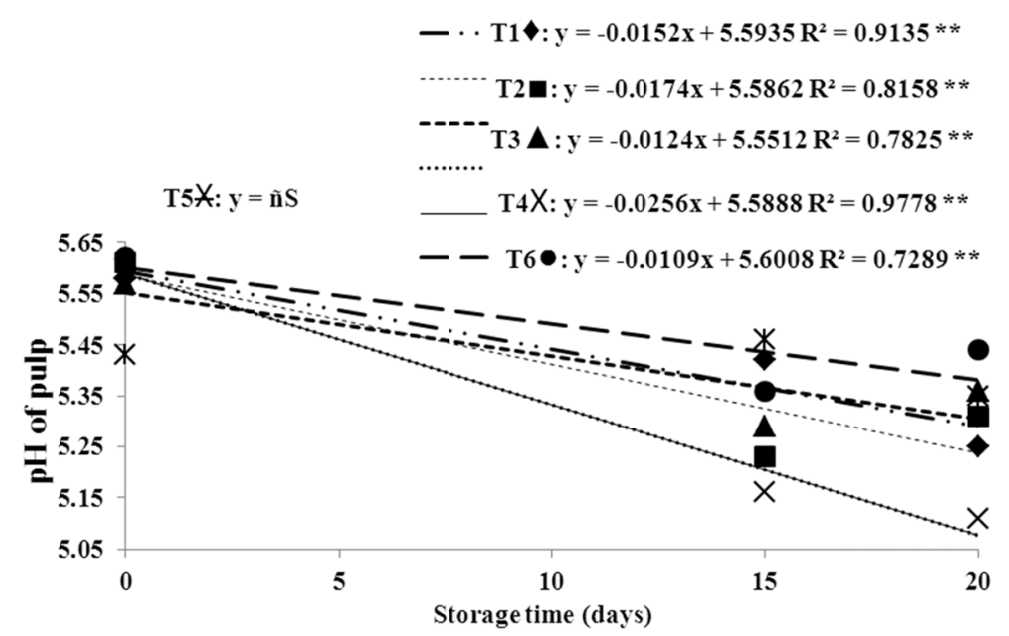

Figure 4. Post-harvest variation of $\mathrm{pH}$ over the storage time of bananas submitted to six treatments (T1 to T6) in Quixeré/CE, 2018

The $\mathrm{pH}$ value declined linearly over time in five treatments (T1, T2, T3, T4, and T6). Only in the T5 treatment ('Pacovan' propagated by meristem), the $\mathrm{pH}$ did not change significantly, showing a mean value of 5.41. Thus, the $\mathrm{T} 5$ was the most effective treatment for $\mathrm{pH}$ control (Table 5 and Figure 4).

The treatments whose acidity accentuated over time had a coefficient of determination higher than $78 \%$ and significance of $1 \%$ probability. The T4 treatment ('Prata-anã' with "ceva"), with a determination coefficient of $97.78 \%$, showed the highest pulp acidification rate ( $2.56 \%$ per day). The T6 treatment ('Silver-dwarf' propagated by meristem), with a determination coefficient of $72.89 \%$, had the lowest rate ( $1.09 \%$ per day), comprising the second most efficient treatment (Table 5 and Figure 4).

Our experiment showed fruit maturity curves of soluble solids and titratable acidity similar to the results of studies using polyethylene (LDPE) bagged banana in green color (Euleutério et al., 2010). However, the pH had the same behavior as the pulp firmness treatments presented by Oliveira (2010) (Figures 1, 3 and 4).

\section{Conclusions}

The storage of banana fruits under refrigeration efficiently delayed the post-harvest maturation and confirmed the viability of using these cultivars on export to countries with a maximum distance of up to 20 days duration from the point of shipment in Brazil.

The cultivar 'Prata-anã' propagated by rhizome with "ceva" was the most efficient as a form of propagation, maintaining the values of soluble solids and acidity in the acceptable range for 20 days, but this treatment obtained the lowest rates of $\mathrm{pH}$.

\section{References}

Allen, R. G., Pereira, L. S., Raes, D., \& Smith, M. (1998). Crop evapotranspiration: Guidelines for computing crop water requirements (FAO, Irrigation and Drainage Paper 56, p. 297). Rome: FAO. Retrieved from https://appgeodb.nancy.inra.fr/biljou/pdf/Allen_FAO1998.pdf

Alves, J. E. (1999). A cultura da banana: Aspectos técnicos, socioeconômicos e agroindustriais (2nd ed., p. 585). Brasília: Embrapa-SPI.

Amorim, E. P., Cohen, K. O., Amorim, V. B. O., Paes, N. S., Sousa, H. N., Santos-Serejo, J. A., \& Silva, S. O. (2011). Caracterização de acessos de bananeira com base na concentração de compostos funcionais. Ciência Rural, 10(2), 121-128. https://doi.org/10.1590/S0103-84782011005000042 
Association of Official Analytical Chemistry. (2002). Official methods of analysis of the Association of Official Analytical Chemistry (17th ed., p. 1115). Washington, AOAC.

Carvalho, H. A. (1984). Qualidade de banana 'Prata' previamente armazenada em saco de polietileno, amadurecida em ambiente com elevada umidade relativa (92f., Dissertação, (Mestrado em Ciências dos Alimentos), Escola Superior de Agricultura de Lavras, Lavras).

Chitarra, M. I. F., \& Chitarra, A. B. (2005). Pós-colheita de frutas e hortaliças: Fisiologia e manuseio (2nd ed., p. 785). Lavras: UFLA.

Damatto Junior, E. R., Campos, A. J., Manoel, L., Moreira, G. C., Leonel, S., \& Evangelista, R. M. (2005). Produção e caracterização de frutos de bananeira 'Prata-Anã' e 'Prata Zulu'. Revista Brasileira de Fruticultura, 2(3), 440-443. https://doi.org/10.1590/S0100-29452005000300024

Euleutério, M. D., Gioppo, M., Sozim, M., \& Malgarim, M. B. (2010). Avaliação das características fisico-químicas de bananas prata (Musa AAB subgrupo Prata) ensacadas em diferentes tipos de materiais. Revista de Engenharia e Tecnologia, 2(1), 49-56.

FAO. (2015). FAOSTAT Database Results. FAO, Roma. Retrieved from http://apps.fao.org

Ferreira, D. F. (2017). Sisvar: A computer statistical analysis system for windows version 5.6. Ciência Agrotecnologia, 38(2), 109-112. https://doi.org/10.1590/S1413-70542014000200001

Gomes, F. P. (2009). Curso de estatística experimental (15th ed., p. 451). Piracicaba: FEALQ.

Guerra, A. G., Medeiros, A. A., Moreira, M. A. B., Dantas, J. A., \& Medeiros, A. C. (2009). Tecnologia para o cultivo da bananeira (1st ed., p. 42). Natal: EMPARN.

Instituto Adolfo Lutz. (2008). Métodos químicos e físicos para análise de alimentos (4th ed., p. 1020). São Paulo: Inst. Adolfo Lutz.

Leite, G. A., Medeiros, E. V., Mendonça, V., Moraes, P. L. D., Lima, L. M., \& Xavier, I. F. (2010). Qualidade pós-colheita da banana 'pacovan' comercializada em diferentes estabelecimentos no município de Mossoró-RN. Revista Brasileira de Ciências Agrárias, 5(3), 322-327. https://doi.org/10.5039/agraria. v5i3a614

Mendonça, V., Gontijo, T. C. A., Arruda, N. A. A., Dantas, D. J., \& Martins, P. C. C. (2003). Propagação da Bananeira e Cuidados na Instalação do Pomar. Revista Eletrônica de Agronomia, 3(3).

Menezes, J. B., \& Alves, R. E. (1995). Fisiologia e tecnologia pós-colheita do pedúnculo do caju (Documentos 17, p. 20). Fortaleza: EMBRAPA-CNPAT.

Oliveira, C. G. (2010). Caracterização pós-colheita de banana 'Prata-anã' e seu híbrido PA42-44 armazenado sob refrigeração (p. 74, Dissertação (Mestrado em Agronomia), Universidade Estadual de Montes Claros, Montes Claros).

Pacheco-Delahaye, E., \& Testa, G. (2005). Evaluación nutricional, física y sensorial de panes de trigo y plátano verde. Interciencia, 30(5), 300-304.

Pontes, S. F. O. (2009). Processamento e qualidade de banana da terra (Musa sapientum) desidratada (p. 86, Dissertação (Mestrado em Engenharia de Alimentos), Universidade Estadual do Sudoeste da Bahia-UESB, Itapetinga).

Queiroga, F. L. M. (2015). Análise de adubos e adubação necessárias para a condução de uma hectare de banana desenvolvida no modelo convencional de produção para o município de Quixeré/CE.

Sant Anna, M., \& Russo, A. (2013). Uso racional da vitamina C (ácido ascórbico) (p. 8). Brasília: Cebrim/CFF.

Souza, M. E., Leonel S., Martins R. L., \& Segtowick, E. C. S. (2013). Caracterização físico-química e avaliação sensorial dos frutos de bananeira. Nativa, 01(01), 13-17. https://doi.org/10.14583/2318-7670.v01n01a03

Sousa, P. H. M., Maia, G. A., Souza Filho, M. S. M., Figueiredo, R. W., Nassu, R. T., \& Souza Neto, M. A. (2003). Influência da concentração e da proporção fruto: Xarope na desidratação osmótica de bananas processadas. Ciência e Tecnologia Alimentos, 23(Supl.), 126-130. https://doi.org/10.1590/S0101-2061200 3000400024

Strohecker, R., \& Henning, H. M. (1967). Analisis de vitaminas: Métodos comprobados (p. 428). Madrid: Paz Montalvo. 
Wills, R. H. H., Lee, T. H., Graham, D., Mcglasson, W. B., \& Hall, E. G. (1981). Postharvest (p. 163). Westport: AVI.

\section{Notes}

Note 1. The technique called "ceva" provides favorable conditions to banana seedlings at the beginning of root system development, which accelerates the swelling of the lateral buds. This technique comprises the removal of rhizome tillers and the maintenance of them on soil surface, under shade, for 21 days (Mendonça et al., 2003).

\section{Copyrights}

Copyright for this article is retained by the author(s), with first publication rights granted to the journal.

This is an open-access article distributed under the terms and conditions of the Creative Commons Attribution license (http://creativecommons.org/licenses/by/4.0/). 